\title{
Experimental herpes-like viral infections in marine bivalves: demonstration of interspecies transmission
}

\author{
Isabelle Arzul, Tristan Renault*, Cécile Lipart \\ Institut français de recherche pour l'exploitation de la mer (IFREMER), Laboratoire de Génétique et Pathologie, \\ 17390 La Tremblade, France
}

\begin{abstract}
Since 1972, herpes-like virus infections have been reported in several marine bivalve species around the world. Viral detection was often associated with high mortality rates in larvae and spat. To determine whether a single virus is able to infect different bivalve host species, we carried out experimental transmission assays. As a first step, 8 assays were performed to infect axenic Crassostrea gigas larvae with virus from infected C. gigas larvae using a previously described protocol. The protocol appeared reliable and PCR was confirmed as a powerful technique for detecting viral DNA in experimentally infected oysters. The defined protocol was then applied to infect different bivalve species. Interspecies viral transmission was demonstrated under laboratory conditions. The same phenomenon may occur in private hatcheries and may be promoted by intensive rearing conditions. This hypothesis is reinforced by reports of concomitant mortalities in the larvae of several bivalve species and by the first molecular analysis of infected larval samples.
\end{abstract}

KEY WORDS: Herpes-like virus - Marine bivalves · Interspecies transmission - Host specificty · Experimental infection

Resale or republication not permitted without written consent of the publisher

\section{INTRODUCTION}

Oyster mortalities associated with the detection of a herpes-like virus were first reported in adult eastern oysters Crassostrea virginica in 1972 in the United States of America (Farley et al. 1972). Since 1991, further herpes-like virus infections have been documented in different parts of the world in different marine mollusc species. Viral detection was often associated with high mortality rates in spat and larvae of farmed bivalves, including Japanese oyster C. gigas (Hine et al. 1992, Nicolas et al. 1992, Renault et al. 1994a,b) and European flat oyster Ostrea edulis (Comps \& Cochennec 1993, Renault et al. 2000b). More recently, herpes-like viruses were observed in Australia in adult O. angasi (Hine \& Thorne 1997) and in Tiostrea chilensis larvae in New Zealand (Hine et al. 1998). Lastly, herpesviral infections have been observed in European clam Ruditapes decussatus (Renault \&

*Corresponding author. E-mail: trenault@ifremer.fr
Arzul 2001) and Manila clam R. philippinarum larvae (Renault 1998). Herpesviruses infecting bivalves are ubiquitous, but it is not known if these pathogenic agents represent different viruses specifically infecting a host species or a single virus infecting several host species. In natural settings, vertebrate herpesviruses are associated with a single host species, and the question arises as to whether bivalve herpesviruses also present high host specificity. There are only a few reports of transmission of viruses between different marine bivalve species. However, some results are considered preliminary, or the evidence for a viral aetiology for some of the diseases has been questioned (Elston 1997). No data are available on the specificity of herpes-like viruses for marine bivalves.

Considering mortality reports and economic importance of shellfish culture, specific and sensitive diagnosis methods such as the polymerase chain reaction (PCR) (Renault et al. 2000a) were developed to enable rapid detection of herpes-like viruses from many samples. As there were no bivalve cell lines in which to grow the virus, a protocol was perfected to experimen- 
tally transmit herpes-like viruses to axenic Crassostrea gigas larvae (Le Deuff et al. 1994). This method allows the study of viral infection, diagnosis and virion production. In the present study, those first trials were repeated and improved to confirm assay reliability. Moreover, infection results were monitored by PCR. We report herein protocol improvements, notably for recovery of infected larvae and in PCR analysis, and the application of a method to infect larvae of different bivalve species. The method developed must demonstrate that viral particles in challenged larvae are not simply those remaining from the inoculum. Trials were conducted in an attempt to transmit a herpes-like virus infecting C. gigas larvae to C. angulata, C. rivularis and Ostrea edulis larvae, and a herpes-like virus infecting Ruditapes philippinarum larvae, to C. gigas larvae.

\section{MATERIALS AND METHODS}

Larval production. Axenic larvae were obtained according to Langdon's method (1983) as previously described (Le Deuff et al. 1994). In brief, Crassostrea gigas adults were sterilized externally before opening them in a sterile area. Oysters were washed for $5 \mathrm{~min}$ with commercial Betadine solution. Gonads were incised and gametes were recovered using a pipette. Fertilization was carried out by mixing spermatozoa and ova at a ratio of 10:1. Axenic larvae were reared in sterile sea water with antibiotics (oxolinic acid, kanamycin, erythromycin and streptomycin sulphate, $0.1 \mathrm{mg} \mathrm{l}^{-1}$; flumequin, $30 \mu \mathrm{g} \mathrm{l}^{-1}$ and penicillin, 100 units $\mathrm{l}^{-1}$ ) at a density of 300 larvae $\mathrm{ml}^{-1}$ in $1 \mathrm{l}$ containers. Larvae were maintained at $25^{\circ} \mathrm{C}$. No algae were added during breeding periods. Non-axenic larvae were produced using the same protocol without decontaminating the broodstock and sea water. Ostrea edulis and C. rivularis larvae were reared in $0.22 \mu \mathrm{m}$ filtered sea water without antibiotics.

Experimental design. The viral source consisted of $400 \mathrm{mg}$ of thawed (from $-20^{\circ} \mathrm{C}$ ) Crassostrea gigas or Ruditapes philippinarum larvae infected with a herpes-like virus, ground using a Dounce tube in $20 \mathrm{ml}$ of sea water and filtered through a $0.22 \mu \mathrm{m}$ filter.

In the first step, 8 experiments were conducted to standardize the infection protocol, larval recovery and PCR analysis. For each experiment, one 11 container of $3 \mathrm{~d}$ old axenic larvae was inoculated with a viral suspension $(8 \mathrm{ml})$ and one $1 \mathrm{l}$ container of $3 \mathrm{~d}$ old axenic larvae was inoculated with sterile sea water $(8 \mathrm{ml})$. When infected larvae ceased to swim, settlement was observed. Larvae were then recovered with the procedure shown in Fig. 1. Before filtering the water using a $20 \mu \mathrm{m}$ mesh, $1 \mathrm{ml}$ of water was sampled (Sample C). Larvae were concentrated and washed in filtered sea water 3 times $(200 \times g$, $15 \mathrm{~min}$ ). One $\mathrm{ml}$ of sea water was collected for PCR analysis after each rinse (Samples S1, S2 and S3). After rinsing, a portion of the larvae was treated as previously described for PCR analysis (Renault et al. 2000a). Another portion was fixed in $3 \%$ glutaraldehyde for transmission electron microscopy (TEM) examination.

In a second step, the protocol was applied to infect larvae belonging to different bivalve species. To infect Crassostrea gigas and C. angulata larvae, axenic larval cultures were directly inoculated with viral suspensions obtained from Ruditapes philippinarum infected larvae and C. gigas infected larvae, respectively.

Infection assays of Ostrea edulis and Crassostrea rivularis larvae required an additional step. That consisted of experimentally infecting C. gigas axenic larvae, which were then inoculated into separate cultures of $O$. edulis and C. rivularis larvae. Larval recovery was performed as described above. The bivalve species tested depended on the availability of broodstock ready to reproduce at the laboratory. For each assay, a bacteriological control was carried out and consisted of inoculating $0.2 \mathrm{ml}$ of rearing water into $10 \mathrm{ml}$ of pancreatic peptone casein $(1.5 \%$.w/v in artificial sea water, $\mathrm{pH} 7.4)$.

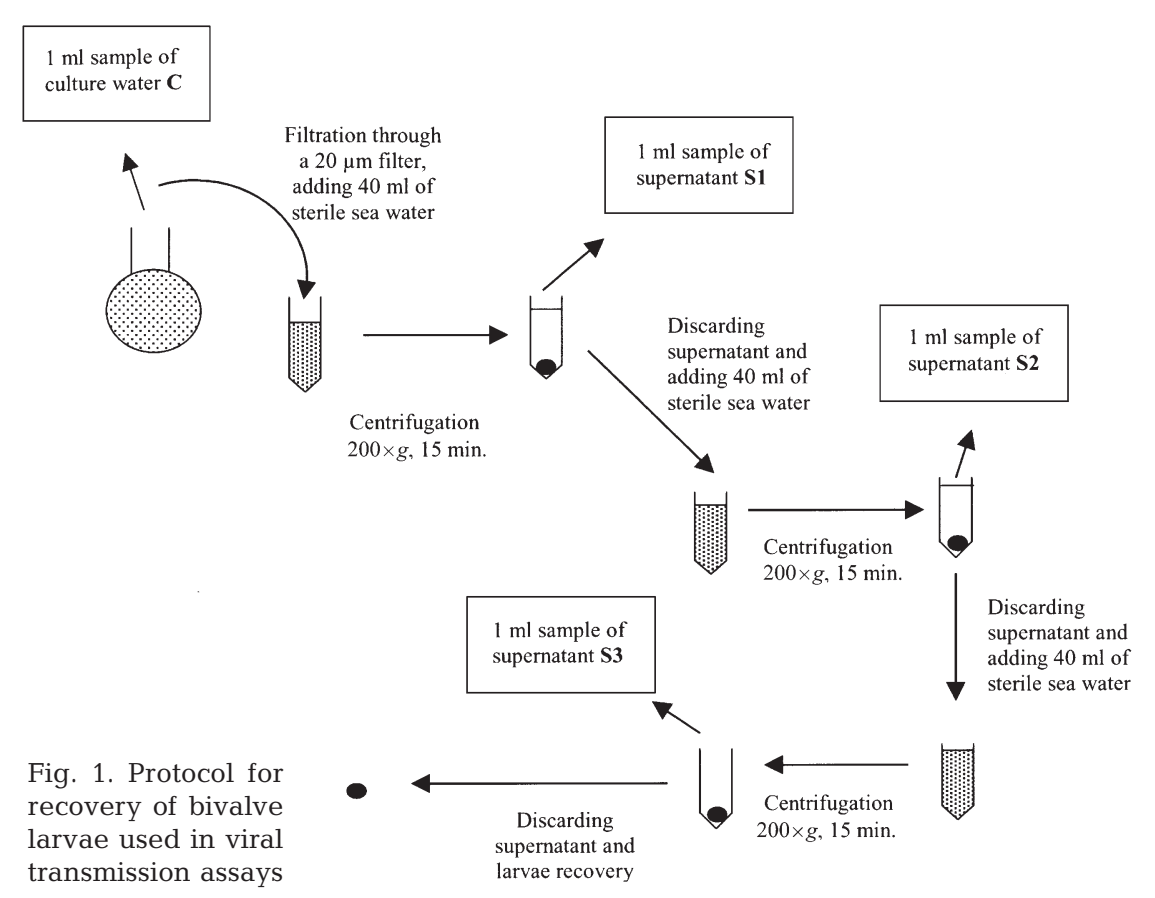


TEM examination. After fixation in 3\% glutaraldehyde in $0.2 \mathrm{M}$ cacodylate buffer ( $\mathrm{pH} 7.2$ ), larval samples were treated as previously described (Renault et al. 1994a). Ultrathin sections stained with uranyl acetate and lead citrate were examined with a JEOL JEM 1200EX transmission electron microscope at $80 \mathrm{kV}$.

PCR analysis. PCR analyses were performed using the C2 (5' CTCTTTACCATGAAGATACCCACC $\left.3^{\prime}\right)$ C6 (5' GTGCACGGCTTACCATTTTT 3') primer pair designed from a viral sequence named $\mathrm{C}$ (Arzul et al. 2001). This viral sequence encodes 2 proteins of unknown functions, and the expected PCR product had a size of $710 \mathrm{bp}$. Thermal cycling was carried out as previously described (Renault et al. 2000a). Fifty $\mu \mathrm{l}$ PCR reactions were performed using Goldstar Polymerase (Eurogentec, Seraing, Belgium), each containing the appropriate buffer, $0.5 \mathrm{mM}$ of each dNTP, 100 ng of each primer, $2.5 \mathrm{mM} \mathrm{MgCl} 2$, and 2.5 units of DNA polymerase. One $\mu \mathrm{l}$ of water containing various amounts of template DNA was added. After 35 amplification cycles, $10 \mu \mathrm{l}$ of each PCR product were subjected to electrophoresis on $1 \%$ agarose gels, stained with ethidium bromide $\left(0.5 \mu \mathrm{g} \mathrm{ml}^{-1}\right)$ and vizualized using a $302 \mathrm{~nm}$ UV transilluminator. Sizes of DNA products were determined relative to the $1 \mathrm{~kb}$ DNA ladder (Eurogentec). The positive control consisted of $10 \mathrm{ng} / \mu \mathrm{l}$ OsHV DNA extracted from purified virus particles (Le Deuff \& Renault 1999). Larval samples were prepared as previously described (Renault et al. 2000a). In brief, $50 \mathrm{mg}$ of frozen larvae were ground in $50 \mu \mathrm{l}$ double-distilled water. Ground larval samples were denatured in a boiling water bath for $10 \mathrm{~min}$ and centrifuged at $1000 \times g$ for $5 \mathrm{~min}$. Supernatants were recovered and immediately diluted 10 -fold in doubledistilled water and frozen at $-20^{\circ} \mathrm{C}$.

\section{RESULTS}

\section{Intraspecies transmission assays}

Six to $10 \mathrm{~d}$ after inoculation of the viral suspension into the containers of axenic larvae of Crassostrea gigas, larvae ceased to swim and settled to the bottom of the containers in all 8 transmission trials (Table 1). Larvae exhibited velar lesions and swollen cells as previously described (Le Deuff et al. 1994, 1996) (Table 1). The $\mathrm{C}, \mathrm{S} 1$ and $\mathrm{S} 2$ samples were positive by PCR (Table 1, Fig. 2). The S3 samples showed negative results by PCR (Table 1, Fig. 2). After rinsing, viral DNA was still detected in larval samples (Fig. 2). TEM examination of larvae revealed intranuclear and intracytoplasmic herpes-like viral particles (Table 1, Fig. 3) as previously described (Le Deuff et al. 1994, 1996). No gross sign was observed in negative controls (Table 1).

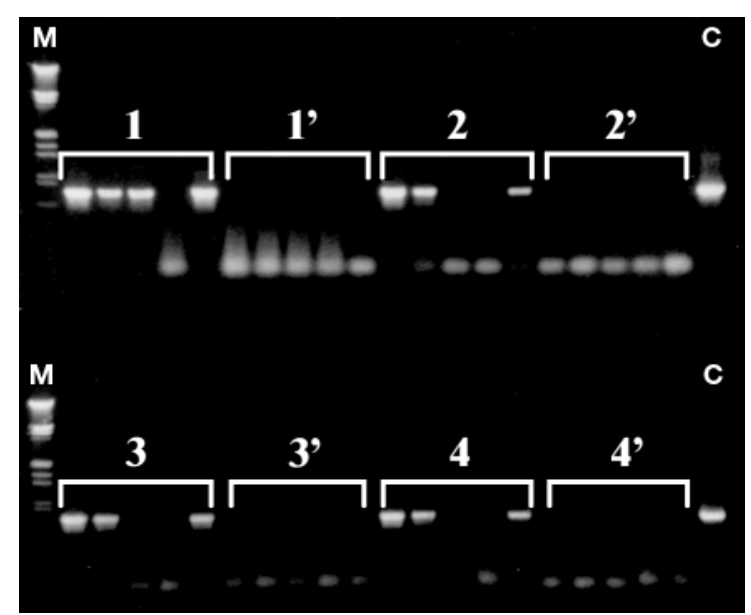

Fig. 2. PCR results of 1 intraspecies and 3 interspecies transmission assays using the primer pair C2-C6. 1: Infection of Crassostrea gigas axenic larvae by a viral suspension obtained from infected C. gigas larvae. 1': Negative control. 2: Infection of $C$. angulata axenic larvae by a viral suspension obtained from infected C. gigas larvae. 2': Negative control. 3: Infection of Ostrea edulis non axenic larvae by contact with infected C. gigas axenic larvae. 3': Negative control. 4: Infection of $C$. rivularis non axenic larvae by contact with infected C. gigas axenic larvae. 4': Negative control. Each group of 5 lanes shows the results of amplification of C, S1, S2, S3 and larval samples, respectively. M: $1 \mathrm{~kb}$ DNA ladder (Eurogentec) and C: positive control (10 ng of OsHV DNA)

PCR analysis was negative and no viral particles were detected by TEM (Table 1, Fig. 2). The bacteriological control was negative for each batch of larvae tested.

\section{Interspecies transmission assays}

Exposure of Crassostrea gigas axenic larvae to the viral suspension obtained from infected Ruditapes philippinarum larvae caused settling of larvae $8 \mathrm{~d}$ after challenge (Table 2). Gross signs were associated with

Table 1. PCR and TEM for the 8 axenic Crassostrea gigas larvae viral transmission assays. Challenge containers received the viral suspension while non-challenge containers received sterile water. The 8 trials showed the same results

\begin{tabular}{|c|c|c|c|c|c|c|c|}
\hline & \multirow{2}{*}{$\begin{array}{l}\text { Gross } \\
\text { signs }^{\mathrm{a}}\end{array}$} & \multicolumn{5}{|c|}{ PCR results ${ }^{\mathrm{b}}$} & \multirow{2}{*}{$\begin{array}{l}\text { TEM } \\
\text { results }\end{array}$} \\
\hline & & $\mathrm{C}$ & $\mathrm{S} 1$ & $\mathrm{~S} 2$ & S3 & Larvae & \\
\hline $\begin{array}{l}\text { Challenge } \\
\text { containers }\end{array}$ & + & + & + & + & - & + & + \\
\hline $\begin{array}{l}\text { Non-challenge } \\
\text { containers }\end{array}$ & - & - & - & - & - & - & - \\
\hline \multicolumn{8}{|c|}{$\begin{array}{l}{ }^{a}+: \text { mortality and settling observed, }- \text { : mortality and settling } \\
\text { not observed } \\
{ }^{b}+: \text { product obtained, }-: \text { product not obtained } \\
{ }^{c}+: \text { viral particles observed, }- \text { : viral particles not observed }\end{array}$} \\
\hline
\end{tabular}




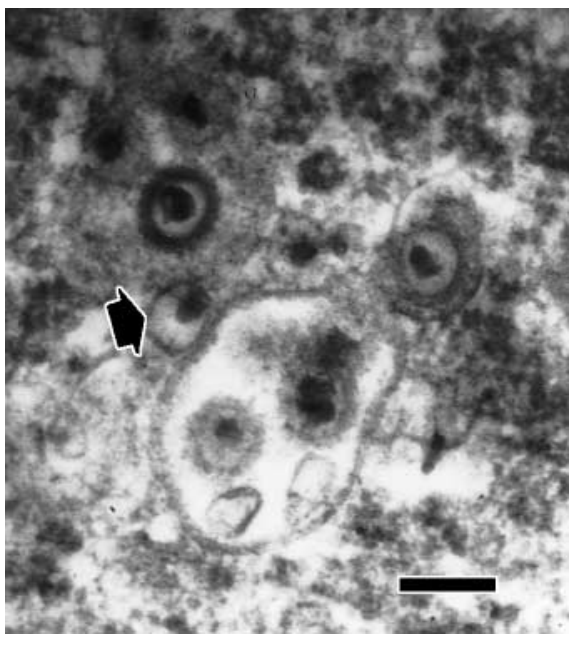

Fig. 3. Infected Crassostrea gigas axenic larva showing herpeslike viral particles (arrow). Scale bar $=150 \mathrm{~nm}$

positive PCR results. Samples C, S1 and S2 showed positive PCR results whereas S3 samples were negative (Table 2). Lastly, larvae were positive using PCR (Table 2). Herpes-like viral particles were detected by TEM in inoculated larvae (data not shown). Nonexposed larvae did not settle, and PCR analysis was negative for Samples C, S1, S2 and S3 and larval samples (Table 2).

Six days after exposure of Crassostrea angulata larvae to C. gigas viral suspension, settling occurred (Table 2). PCR analysis was positive for Samples C, S1 and larval samples (Table 2, Fig. 2). S2 and S3 samples were neg- ative as all negative control samples (Table 2, Fig. 2). TEM examination revealed herpes-like viral particles in challenged $C$. angulata larvae but none in nonchallenged larvae (data not shown).

Two trials consisted of co-habiting $10 \mathrm{~d}$ old Ostrea edulis larvae and $2 \mathrm{~d}$ old Crassostrea rivularis larvae with infected C. gigas axenic larvae. O. edulis larvae settled $6 \mathrm{~d}$ after co-habitation. The C, S1 and larval samples showed positive PCR results; S2 and S3 were negative (Table 2, Fig. 2). Herpes-like viral particles were detected by TEM. Non-challenged larval samples were negative by PCR (Table 2, Fig. 2) and no viral particles were observed by TEM (Table 2 ).

Crassostrea rivularis larvae were recovered $3 \mathrm{~d}$ after cohabitation with infected C. gigas axenic larvae. Massive larval settlement was observed in the challenge container, although no gross sign was observed in the non-challenged container (Table 2). PCR analysis of the $\mathrm{C}, \mathrm{S} 1$ and larval samples from the challenge container was positive whereas all the samples from the non-challenged container were negative (Table 2 , Fig. 2). No TEM examination was carried out for $C$. rivularis larval samples.

\section{DISCUSSION}

Numerous authors have reported experimental herpesviral transmission experiments in higher and lower vertebrates, including fish (Kimura et al. 1981a,b, Wise et al. 1988, McAllister \& Herman 1989). Conversely, there have been very few attempts to transmit viral

Table 2. PCR and TEM results for the 4 interspecies transmission assays

\begin{tabular}{|c|c|c|c|c|c|c|c|c|}
\hline \multirow[t]{2}{*}{ Infected species } & \multirow[t]{2}{*}{ Viral source } & \multirow[t]{2}{*}{ Gross signs $^{a}$} & \multicolumn{5}{|c|}{ PCR results ${ }^{b}$} & \multirow{2}{*}{$\begin{array}{l}\text { TEM } \\
\text { results }\end{array}$} \\
\hline & & & $\mathrm{C}$ & S1 & $\mathrm{S} 2$ & S3 & Larvae & \\
\hline \multirow{2}{*}{$\begin{array}{l}\text { Axenic } \\
\text { larvae } \\
\text { Crassostrea } \\
\text { gigas }\end{array}$} & $\begin{array}{l}\text { Ruditapes philippinarum } \\
\text { viral suspension }\end{array}$ & + & + & + & + & - & + & + \\
\hline & Sterile water & - & - & - & - & - & - & - \\
\hline \multirow{2}{*}{$\begin{array}{l}\text { Axenic } \\
\text { larvae } \\
\text { Crassostrea } \\
\text { angulata }\end{array}$} & $\begin{array}{l}\text { Crassostrea gigas } \\
\text { viral suspension }\end{array}$ & + & + & + & - & - & + & + \\
\hline & Sterile water & - & - & - & - & - & - & - \\
\hline \multirow{2}{*}{$\begin{array}{l}\text { Non axenic } \\
\text { larvae } \\
\text { Ostrea } \\
\text { edulis }\end{array}$} & $\begin{array}{l}\text { Crassostrea gigas } \\
\text { infected axenic larvae }\end{array}$ & + & + & + & - & - & + & + \\
\hline & Healthy axenic larvae & - & - & - & - & - & - & - \\
\hline \multirow{2}{*}{$\begin{array}{l}\text { Non axenic } \\
\text { larvae } \\
\text { Crassostrea } \\
\text { rivularis }\end{array}$} & $\begin{array}{l}\text { Crassostrea gigas } \\
\text { infected axenic larvae }\end{array}$ & + & + & + & - & - & + & ND \\
\hline & Healthy axenic larvae & - & - & - & - & - & - & ND \\
\hline
\end{tabular}


infections to marine molluscs, particularly to bivalves. Some viruses infecting molluscs can be cultured in fish cell lines, including a birnavirus from cultured hard clam Meretrix lusoria (Chou et al. 1994) and the unclassified Akoya virus from Japanese pearl oysters Pinctada fucata martensii (Miyazaki et al. 1999). Both viruses are non-enveloped and may have a wider host range than enveloped ones. They can be cultivated in vitro on heterologous cell lines. Since the herpes-like virus isolated from infected Crassostrea gigas larvae was not able to multiply in fish and insect cell lines (Le Deuff 1995), a protocol was developed to experimentally transmit the virus to $C$. gigas axenic larvae (Le Deuff et al. 1994, 1996). This technique constitutes an alternative method to cell culture for diagnosis and production of C. gigas herpes-like virus and to study viral pathogenesis. However, the amounts of virus inoculated into containers of axenic larvae remain unknown. A PCR internal standard that allows viral DNA quantitation is available (T.R. unpubl. data), but the amount of DNA in larval samples is not representative of viral infectivity because only enveloped particles are infectious.

Concerning the 8 transmission trials with axenic Crassostrea gigas larvae, PCR and TEM analyses confirmed the first assays previously reported (Le Deuff et al. 1994, 1996). However, the protocol was improved, particularly for larval recovery (Fig. 1) and analysis. The real intent was to recover infected larvae with no remaining contamination from inoculated virus. Successive washes may eliminate residual viral DNA from the virus inoculum. Viral DNA detected after the rinsing steps probably corresponds to progeny virus, and hence indicates effective larval experimental infections. Specific molecular tools such as PCR (Renault et al. 2000a) have been developed since the first experimental transmission trials (Le Deuff et al. 1994, 1996). PCR gave results quickly, which were confirmed by TEM analysis (Fig. 3). Detection of intracellular particles by TEM demonstrated that positive PCR results correspond to real infections and not particles tightly adhered to larval surface.

This reliable experimental protocol was used to infect other bivalve species. PCR was used as the most suitable technique for further analysis of larvae. A herpesvirus infecting one bivalve species can infect other bivalve species, specifically, a herpesvirus infecting Ruditapes philippinarum was transmitted to Crassostrea gigas, and a herpesvirus infecting $C$. gigas was transmitted to $C$. angulata, C. rivularis and Ostrea edulis larvae. But does this phenomenon occur in the field or in hatcheries? Concomitant herpes-like viral infections were confirmed by TEM examination of cultured C. gigas and O. edulis (Renault et al. 2000b) and of cultured C. gigas and R. philippinarum (T.R. unpubl. data). Interspecies transmission appears possible under hatchery rearing conditions. This hypothesis was reinforced by molecular analysis of infected larvae belonging to different bivalve species, $C$. gigas, $O$. edulis, R. philippinarum and $R$. decussatus. Viral DNA sequences were found to be similar for viruses infecting these different bivalve species (I.A. unpubl. data). The detection of viral DNA by PCR in some samples presenting anomalous mortalities may lead to some precautionary measures being taken in order to prevent the spread of viral infections among all larval broods in a hatchery. Moreover, the detection of herpes-like viruses in different bivalve species highlights the risk of rearing different mollusc species together in the same hatchery.

Herpesviruses could have evolved with their bivalve host for a very long period and they would then constitute good molecular markers to understand bivalve evolution and 'migration'. Evolutionary studies of vertebrate herpesviruses suggest that a common viral ancestor existed and that herpesviruses have evolved by substitution, deletion, insertion of nucleotides and recombination processes resulting in gene duplication and divergence, capture of host genes and gene rearrangement (McGeoch 1992, Davison \& McGeoch 1995). Persistent viruses, such as herpesviruses, are bound to their hosts by the constraints of specificity which would certainly favor their coevolution (Khanna et al. 1997). Many studies consist of tracing relationships between genotypes and human ethnic groups by analysing DNA polymorphism of HSV-1 strains present in populations of various countries. HSV-1 genotyping appears to be a reliable molecular marker to understand population migrations (Umene \& Sakaoka 1997, 1999). Molecular evolutionary genetic analysis shows that Epstein Barr Virus (EBV) isolates have evolved differently according to the regions of the world considered (Khanna et al. 1997).

Coevolution over a long period between a bivalve ancestor and a herpesvirus ancestor is suspected, possibly explaining herpesvirus detection in different host species belonging to different genera and presenting different ways of life and biotopes. In the field, oysters settle on hard substratum whereas clams, which are burrower bivalves, prefer soft substratum. However, both species now being developed together in hatcheries and the proximity it creates may facilitate pathogen transmission and infection of new host species. Bivalve herpesviruses, like vertebrate herpesviruses, may be confined to a single host species in the field, but intensive rearing conditions promote transmission to new host species. Since bivalves have differentiated and specialized, herpesviruses may use conserved systems among bivalves to enter and settle in their host. 
Acknowledgements. Dr A. Gérard is acknowledged for allowing this work at the IFREMER Station in La Tremblade (Charente maritime, France). This research was supported in part by European Union fundings (contracts E.C. no. FA-S2 9052 and Fair-CT-4334). This study would not have been possible without the valuable contribution of IFREMER hatchery and nursery technicians. We also thank Dr P. Dixon and Dr R. M. Le Deuff (CEFAS, Weymouth, UK) for critical comments on the manuscript.

\section{LITERATURE CITED}

Arzul J, Renault T, Lipart C, Davison AJ (2001) Evidence for interspecies transmission of oyster herpes virus in marine bivalves. J Gen Virol 82:865-870

Chou HY, Li HJ, Lo CF (1994) Pathogenicity of a birnavirus to hard clam (Meretrix lusoria) and effect of temperature stress on its virulence. Fish Pathol 29(3):171-175

Comps M, Cochennec N (1993) A herpes-like virus from the European oyster Ostrea edulis. J Invertebr Pathol 62: 201-203

Davison AJ, McGeoch DJ (1995) Herpesviridae. In: Gibbs AJ,

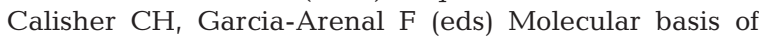
virus evolution. Cambridge University Press, Cambridge, p 290-309

Elston R (1997) Bivalve mollusc viruses. World J Microbiol Biotechnol 13:393-403

Farley CA, Banfield WG, Kasnic JRG, Foster WS (1972) Oyster herpes-type virus. Science 178:759-760

Hine PM, Thorne ET (1997) Replication of herpes-like viruses in haemocytes of adult flat oysters Ostrea angasi (Sowerby, 1871): an ultrastructural study. Dis Aquat Org 29(3): 197-204

Hine PM, Wesney B, Hay BE (1992) Herpesvirus associated with mortalities among hatchery-reared larval Pacific oysters, Crassostrea gigas. Dis Aquat Org 12(2):135-142

Hine PM, Wesney B, Besant O (1998) Replication of a herpeslike virus in larvae of the flat oyster Tiostrea chilensis at ambient temperatures. Dis Aquat Org 32(3):161-171

Khanna R, Slade RW, Poulsen L, Moss DJ, Burrows SR, Nicholls J, Burrows JM (1997) Evolutionary dynamics of genetic variation in Epstein-Barr virus isolates of diverse geographical origins: evidence for immune pressureindependent genetic drift. J Virol 71(11):8340-8346

Kimura T, Yoshimizu M, Tanaka M (1981a) Studies on a new virus (OMV) from Oncorhynchus masou - II. Oncogenic nature. Fish Pathol 15(3/4):149-153

Kimura T, Yoshimizu M, Tanaka M, Sannohe H (1981b) Studies on a new virus (OMV) from Oncorhynchus masou - I. Characteristics and Pathogenicity. Fish Pathol 15(3/4): 143-147

Langdon C (1983) Growth studies with bacteria-free oyster (Crassostrea gigas) larvae fed semi-defined artificial diets. Biol Bull 164(2):227-235

Le Deuff RM (1995) Contribution à l'étude de virus de mollusques marins apparentés aux Iridoviridae et aux Her-

Editorial responsibility: Albert Sparks,

Seattle, Washington, USA pesviridae. Thèse de doctorat, Université de Bordeaux II

Le Deuff RM, Renault T (1999) Purification and partial genome characterization of a herpes-like virus infecting the Japanese oyster, Crassostrea gigas. J Gen Virol 80: $1317-1322$

Le Deuff RM, Nicolas JL, Renault T, Cochennec N (1994) Experimental transmission of herpes-like virus to axenic larvae of Pacific oyster, Crassostrea gigas. Bull Eur Assoc Fish Pathol 142(2):69-72

Le Deuff RM, Renault T, Gérard A (1996) Effects of temperature on herpes-like virus detection among hatcheryreared larval Pacific oyster Crassostrea gigas. Dis Aquat Org 24(2):149-157

McAllister PE, Herman RL (1989) Epizootic mortality in hatchery-reared lake trout Salvelinus namaycush caused by a putative virus possibly of the herpesvirus group. Dis Aquat Org 6(2):113-119

McGeoch DJ (1992) Molecular evolution of large DNA viruses of eukaryotes. Semin Virol 3:399-408

Miyazaki T, Goto K, Kobayashi T, Kageyama T, Miyata M (1999) Mass mortalities associated with a virus disease in Japanese pearl oysters Pinctada fucata martensii. Dis Aquat Org 37(1):1-12

Nicolas JL, Comps M, Cochennec N (1992) Herpes-like virus infecting Pacific oyster larvae, Crassostrea gigas. Bull Eur Assoc Fish Pathol 12(1):11-13

Renault T (1998) Infections herpétiques chez les invertébrés: détection de virus de type herpès chez les mollusques bivalves marins. Virologie 2:401-403

Renault T, Arzul I (2001) Herpes-like virus infections in hatchery-reared bivalve larvae in Europe: specific viral DNA detection by PCR. J Fish Dis 24:161-167

Renault T, Cochennec N, Le Deuff RM, Chollet B (1994a) Herpes-like virus infecting Japanese oyster (Crassostrea gigas) spat. Bull Eur Assoc Fish Pathol 14(2):64-66

Renault T, Le Deuff RM, Cochennec N, Maffart P (1994b) Herpesviruses associated with mortalities among Pacific oyster, Crassostrea gigas, in France-comparative study. Rev Méd Vét 145(10):735-742

Renault T, Le Deuff RM, Lipart C, Delsert C (2000a) Development of a PCR procedure for the detection of an herpeslike virus infecting oysters in France. J Virol Meth 88: 41-50

Renault T, Le Deuff RM, Chollet B, Cochennec N, Gérard A (2000b) Concomitant herpes-like virus infections among hatchery-reared larvae and nursery-cultured spat Crassostrea gigas and Ostrea edulis. Dis Aquat Org 42:173-183

Umene K, Sakaoka H (1997) Populations of two Eastern countries of Japan and Korean and with a related history share a predominant genotype of herpes simplex virus type 1 . Arch Virol 142:1953-1961

Umene K, Sakaoka H (1999) Evolution of herpes simplex virus type 1 under herpesviral evolutionary processes. Arch Virol 144(4):637-656

Wise JA, Harell SF, Busch RL, Boyle JA (1988) Vertical transmission of channel catfish virus. Am J Vet Res 49(9): 1506-1509

Submitted: January 18, 2001; Accepted: April 28, 2001

Proofs received from author(s): July 26, 2001 